\title{
MEDIA PEMBELAJARAN PUZZLE UNTUK MENINGKATKAN HASIL BELAJAR SISWA KELAS IV PADA KOMPETENSI PENGETAHUAN IPA
}

\author{
I Wayan Widiana ${ }^{1}$, Ndara Tanggu Rendra ${ }^{2}$, Ni Wayan Wulantari ${ }^{3}$, \\ ${ }^{1,2,3}$ Prodi Pendidikan Guru Sekolah Dasar, ${ }^{3}$ Prodi Teknologi Pendidikan, FIP Universitas Pendidikan Ganesha \\ e-mail: wayanwidiana85@undiksha.ac.id
}

\begin{abstract}
ABSTRAK
Penelitian ini bertujuan untuk (1) mendeskripsikan rancang bangun pengembangan media pembelajaran puzzle, (2) mengetahui validitas hasil pengembangan media pembelajaran puzzle, dan (3) mengetahui efektivitas pengembangan media pembelajaran puzzle. Jenis penelitian ini adalah penelitian pengembangan menggunakan model ADDIE. Data dalam penelitian ini menggunakan metode wawancara, kuesioner, tes dan pencatatan dokumen. Data yang terkumpul dianalisis dengan teknik deskriptif kualitatif, analisis deskriptif kuantitatif, dan analisis statistik inferensial (uji-t). Hasil penelitian menunjukkan bahwa : (1) Rancang bangun pengembangan media pembelajaran puzzle melalui model ADDIE yang terdiri atas analisis (Analyze), rancang bangun (Design), pengembangan (Development), Implementasi (Implementation), dan evaluasi (Evaluation). (2) Produk dinyatakan valid dilihat dari review para ahli dan uji coba siswa dengan (a) hasil review ahli isi mata pelajaran menunjukkan media pembelajaran puzzle berkualifikasi sangat baik $(97,14 \%)$, (b) hasil ahli desain pembelajaran menunjukkan media pembelajaran puzzle berkualifikasi baik $(88 \%)$, (c) hasil ahli media pemebelajaran menunjukkan media pembelajaran puzzle berkualifikasi cukup (70\%), (d) hasil uji coba perorangan menunjukkan media pembelajaran puzzle berkualifikasi sangat baik (94\%), uji coba kelompok kecil menunjukkan media pembelajaran puzzle berkualifikasi sangat baik (93\%), dan uji coba lapangan berkualifikasi baik $(87,33 \%)$. (3) Uji efektifitas media pembelajaran puzzle menunjukkan bahwa hasil $t_{\text {hitung }}(9,240)>t_{\text {tabel }}(2,056)$. Ini berarti media pembelajaran puzzle efektif untuk meningkatkan hasil belajar siswa kelas IV pada kompetensi pengetahuan IPA di SD Negeri 2 Bengkala, Kecamatan Kubutambahan, Kabupaten Buleleng tahun Pelajaran 2018/2019.
\end{abstract}

Kata Kunci : Pengembangan, Puzzle, IPA, validitas, efektivitas.

\begin{abstract}
This study aims to (1) describe the design of the development of puzzle learning media, (2) determine the validity of the results of the development of puzzle learning media, and (3) determine the effectiveness of the development of puzzle learning media. This type of research is development research using the ADDIE model. The data in this study used interviews, questionnaires, tests and document records. The collected data were analyzed by qualitative descriptive techniques, quantitative descriptive analysis, and inferential statistical analysis (t-test). The results showed that: (1) The design of the development of puzzle learning media through the ADDIE model consisted of analysis (Analyze), design (Development), development (Development), Implementation (Implementation), and evaluation (Evaluation). (2) Products declared valid seen from the reviews of experts and students with (a) the results of review of subject matter experts showed that the puzzle learning media was very well qualified $(97.14 \%)$, (b) the results of learning design experts showed good quality learning media (88\%), (c) the results of learning media experts show that the puzzle learning media has sufficient quality (70\%), (d) the results of individual trials show that puzzle learning media is very well qualified (94\%), small group trials show puzzle learning media very good quality (93\%), and field trials are very good qualified (87,33\%). (3) Test the effectiveness of puzzle learning media shows that the results of tcount (9.240)> t table (2.056). This means that there is effectiveness in puzzle learning media to improve learning outcomes of fourth grade students in science knowledge competencies in Bengkala 2 Elementary School, Kubutambahan District, Buleleng Regency 2018/2019 academic year.
\end{abstract}

Keywords : Development, puzzle learning media, science, validity, effectiveness. 


\section{Pendahuluan}

Kurikulum yang diterapkan di Indonesia adalah kurikulum 2013. Kurikulum 2012 memiliki 4 aspek yang meliputi aspek pengetahuan, aspek keterampilan, aspek perilaku dan aspek sikap Menurut Putri, dkk (2018: 212). Kurikulum 2013 membawa amanah untuk menanamkan nilai pancasila pada diri anak melalui pendidikan karakter. Dalam pengimplementasiannya, kurikulum 2013 menggambungkan mata pelajaran menjadi satu dibawah naungan mata pelajaran tematik yang bersifat integrated. Suarjana dan Japa (2015 :3). Pendidikan menjadi hal yang utama dalam upaya meningkatkan kualitas sumber daya manusia. Pembaharuan kurikulum dilakukan sebagai upaya dalam memperbaiki aspek pembelajaran dan meningkatkan kualitas pendidikan di sekolah sehingga mutu pendidikan menjadi lebih baik. keberhasilan pendidikan juga bergantung pada guru Karena guru merupakan kunci terselenggaranya suatu proses pembelajaran yang membelajarkan peserta didik. pengembangan materi-materi yang dulu dirancang 1 mata pelajaran dikembangkan menjadi materi-materi terintegrasi dan terpadu dalam suatu tema yang disebut tematik terpadu. Kurikulum 2013 dalam Permendikbud Nomor 57 Tahun 2014, IPA bukan lagi merupakan bidang studi namun sebagai muatan pelajaran yang diintegrasikan ke mata pelajaran lain. Kurikulum 2013 yang mengusung pembelajaran yang terpadu antara materimateri dari berbagai bidang studi, yang dimana IPA menjadi salah satunya. IImu pengetahuan alam, yang sering disebut juga dengan istilah pendidikan sains, disingkat menjadi IPA. Menurut Susanto (2013: 167), sains atau IPA adalah usaha manusia dalam memahami alam semesta melalaui pengamatan yang tepat pada sasaran, serta menggunakan prosedur, dan dijelaskan dengan penalaran sehingga mendapatkan suatu kesimpulan.

Kesulitan-kesulitan guru mengajar pada kurikulum 2013 adalah keterbatasan media pembelajaran yang digunakan terutama pada siswa sekolah dasar. Minimnya penggunaan media pembelajaran mengakibatkan proses pembelajaran berlangsung kurang maksimal. Menurut hasil observasi yang dilakukan ditemukan bahwa seluruh SD di gugus III Rambutan Kecamatan Kubutambahan kurang inovatif dalam penggunaan media pembelajaran, dikarenakan hanya menggunakan satu jenis media saat pembelajaran serta terdapat satu SD dalam penggunaan media pembelajaran tidak sesuai dengan karakteristik siswa yaitu SD Negeri 2 Bengkala dikarenakan terdapat siswa tuna wicara di SD tersebut. Penggunaan media pembelajaran di seluruh SD Gugus III Rambutan Kecamatan Kubutambahan, dapat dilihat pada Tabel 1.

Tabel 1. Penggunaan Media Pembelajaran di Seluruh SD Gugus III Rambutan Kecamatan Kubutambahan

\begin{tabular}{ll}
\hline \multicolumn{1}{c}{ Sekolah } & \multicolumn{1}{c}{ Media Pembelajaraan } \\
\hline SD Negeri 1 Bila & Media Audio Visual (Video) \\
SD Negeri 2 Bila & Media Visual (Gambar) \\
SD Negeri 1 Bengkala & Media Audio Visual (Video) \\
SD Negeri 2 Bengkala & Media Visual (Gambar) \\
\hline
\end{tabular}

Berdasarkan data di atas, media pembelajaran yang ada saat ini yaitu media berbasis visual dan media berbasis audio visual. Selain itu, dalam pemilihan penggunaan media pembelajaran haruslah sesuai dengan karakteristik siswa dan media pembelajaran penting digunakan saat proses pembelajaran untuk membangkitkan minat siswa untuk menngikuti proses pembelajaran. Media pembelajaran adalah segala sesuatu yang dapat digunakan untuk menyalurkan pesan atau bahan pembelajaran sehingga mampu merangsang perhatian, minat, pikiran, dan perasaan belajar siswa untuk mencapai tujuan pembelajaran yang telah ditetapkan (Arsyad, 2009). Sedangkan Fungsi media pembelajaran menurut Suryani dan Leo (2012: 146) yaitu "(1) alat bantu untuk mewujudkan situasi belajar mengajar yang efektif), (2) bagian integral dari keseluruhan situasi belajar mengajar, (3) meletakkan dasar-dasar yang konkret dari konsep yang abstrak sehingga mengurangi 
pemahaman yang bersifat verbalisme, (4) membangkitkan motivasi belajar peserta didik, (5) mempertinggi mutu belajar mengajar".

Sejalan dengan pendapat-pendapat para ahli di atas, hasil penelitian Sudarmika (2018) menyatakan bahwa media pembelajaran ular tangga mampu meningkatkan minat belajar siswa. Darmawan (2019) menyatakan bahwa media pembelajaran puzzle mampu meningkatkan konsentrasi belajar siswa. Selain itu, hasil penelitian. Hasil penelitian lainnya yang dilakukan oleh Martini (2018) menyatakan bahwa media pembelajaran wayang tokoh dongeng mampu meningkatkan hasil belajar siswa. Kemudian penelitian yang dilakukan oleh Ponza (2018) mendapatkan hasil bahwa media video animasi efektif dalam meningkatkan hasil belajar siswa. Sedangkan penelitian yang dilakukan oleh Putri (2017) mendapatkan hasil penelitian bahwa media pembelajaran video bahasa isyarat efektif meningkatkan motivasi belajar siswa. Serta penelitian yang dilakukan oleh Suarmika (2018) mendapatkan hasil peneltian bahwa media pembelajaran film pendek berbasis kearifan lokal efektif meningkatkan hasil belajar siswa.

Hasil-hasil penelitian tersebut dapat membuktikan bahwa penggunaan media pembelajaran sangat penting dan efektif digunakan dalam pembelajaran. Oleh karena itu, dalam penelitian ini dikembangkan media yang cocok digunakan dalam pembelajaran di sekolah dasar yaitu media pembelajaran Puzzle. Alasan media pembelajaran puzzle ini dikembangkan karena melihat kebutuhan dari siswa di SD Negeri 2 Bengkala yang menginginkan media pembelajaran yang mampu digunakan oleh siswa normal maupun siswa tuna wicara, selain itu media pembelajaran puzzle akan memberikan visualisasi materi yang lebih menarik dikarenakan belajar dibarengi permainan akan menambah minat siswa untuk belajar, sehingga pemahaman materi siswa baik.

Dalam pengembangan media pembelajaran puzzle menggunakan model ADDIE. "Model ini terdiri atas lima langkah, yaitu (1) Analisis (Analyze), (2) Desain (Design), (3) Pengembangan (Development), (4) Implementasi (Implementation), dan (5) Evaluasi (Evaluation)" (Tegeh dan Kirna, 2014:16). Berdasarkan paparan tersebut, maka pada penelitian ini dikembangkan media pembelajaran puzzle untuk meningkatkan hasil belajar siswa kelas IV pada kompetensi pengetahuan IPA tahun pelajaran 2018/2019 di SD Negeri 2 Bengkala Kecamatan Kubutambahan Kabupaten Buleleng.

\section{Metode}

Penelitian ini merupakan jenis penelitian pengembangan. Model pengembangan yang digunakan adalah model ADDIE. Pemilihan model ADDIE didasari atas pertimbangan bahwa model ini disusun secara sistematis dalam upaya memecahkan masalah belajar yang berkaitan dengan media pembelajaran yang sesuai dengan karakteristik siswa.

Pada penelitian pengembangan media pembelajaran puzzle ini menggunakan empat metode pengumpulan data, yaitu (1) Metode wawancara, dilakukan pada saat mewawancarai guru kelas IV di SD Negeri 2 Bengkala. Metode ini digunakan dalam analisis awal untuk mengetahui masalah yang ada di kelas IV. (2) Metode kuesioner, digunakan saat mengukur validitas produk pada tahap review oleh para ahli dan oleh siswa. (3) Metode tes, digunakan untuk mengetahui efektivitas penggunaan media pembelajaran puzzle terhadap kompetensi pengetahuan IPA siswa kelas IV di SD Negeri 2 Bengkala. (4) Metode pencatatan dokumen, digunakan dalam pengumpulan data untuk mendeskripsikan laporan pengembangan media pembelajaran puzzle.

Instrumen yang digunakan untuk mengumpulkan data dalam penelitian pengembangan ini adalah (1) daftar pertanyaan, digunakan untuk mewawancarai guru kelas IV di SD Negeri 2 Bengkala, (2) lembar kuesioner digunakan untuk mengetahui validitas media pembelajaran puzzle, (3) soal tes pilihan ganda digunakan untuk mengumpulkan data nilai kompetensi pengetahuan IPA siswa sebelum dan sesudah menggunakan media pembelajaran puzzle, dan (4) laporan pencatatan dokumen digunakan untuk menjelaskan tentang rancang bangun media pembelajaran puzzle.

Penelitian pengembangan media pembelajaran puzzle ini menggunakan tiga teknik analisis data, yaitu: (1) Analisis deskriptif kualitatif dilakukan dengan cara mengelompokkan 
informasi dari data kualitatif yang berupa masukan, kritikan, tanggapan, dan saran perbaikan yang terdapat pada hasil kuesioner yang diberikan kepada para ahli (ahli isi mata pelajaran, ahli desain pembelajaran, dan ahli media pembelajaran), uji coba perorangan, uji coba kelompok kecil, dan uji coba lapangan. Hasil analisis ini digunakan untuk merevisi produk yang dikembangkan. (2) Analisis deskriptif kuantitatif digunakan untuk mengolah data yang diperoleh melalui kuesioner dalam bentuk persentase. Untuk dapat memberikan makna dan pengambilan keputusan digunakan ketepatan pada Tabel 2 Sebagai berikut

Tabel 2. Konversi Tingkat Pencapaian dengan skala 5

\begin{tabular}{ccc}
\hline Tingkat Pencapaian & Kualifikasi & Keterangan \\
\hline $90 \%-100 \%$ & Sangat baik & Tidak perlu direvisi \\
$75 \%-89 \%$ & Baik & Sedikit direvisi \\
$65 \%-74 \%$ & Cukup & Direvisi secukupnya \\
$55 \%-64 \%$ & Kurang & Banyak hal yang direvisi \\
$0-54 \%$ & Sangat Kurang & Diulang membuat produk \\
\hline
\end{tabular}

(3) Analisis statistik inferensial digunakan untuk menghitung tingkat efektivitas media pembelajaran puzzle terhadap kompetensi pengetahuan IPA siswa kelas IV di SD Negeri 2 Bengkala dengan memberikan pretest dan posttest kepada siswa tersebut. Hasil dari pretest dan posttest kemudian dianalisis menggunakan uji-t. Pengujian hipotesis menggunakan uji-t berkorelasi dengan perhitungan manual. Sebelum melakukan uji hipotesis (uji-t berkorelasi), dilakukan uji prasyarat (normalitas dan homogenitas).

Uji normalitas dilakukan untuk mengetahui apakah sebaran skor pada setiap variabel berdistribusi normal atau tidak, untuk itu dapat digunakan rumus Chi-Kuadrat. Uji homogenitas ini dimaksudkan untuk mencari bahwa dua atau lebih kelompok data sampel berasal dari populasi yang memiliki variasi yang sama. Kriteria pengujian $\mathrm{HO}$ diterima jika Fhitung < Ftabel yang berarti sample homogen. Uji dilakukan pada taraf signifikan 5\% dengan derajat kebebasan untuk pembimbing $n 1-1$ dan derajat kebebasan untuk penyebut n2 - 1. Setelah dilakukan uji normalitas dan homogenitas, selanjutnya dilakukan uji hipotesis.

\section{Hasil dan Pembahasan}

\section{Rancang Bangun Media}

Penelitian ini dilaksanakan pada kelas IV semester genap di SD Negeri 2 Bengkala. Subjek dalam penelitian ini adalah seluruh siswa kelas IV yang berjumlah 14 orang siswa. Adapun pengembangan media pembelajaran puzzle disesuaikan dengan model ADDIE yang terdiri dari lima tahapan yaitu: (1) Analyze (analisis) yaitu memeriksa masalah yang ada, (2) Design (desain). Tahap mengidentifikas software (photoshop) serta alat dan bahan yang sekiranya digunakan dalam proses pengembangan produk media pembelajaran tersebut. Desain media yang dikembangkan saat ini akan menggunakan berbagai macam warna selain agar lebih inovatif juga mampu menarik minat siswa untuk belajar. Adapun tampilan Desain Media pembelajaran puzzle Inovatif sebagai Berikut 


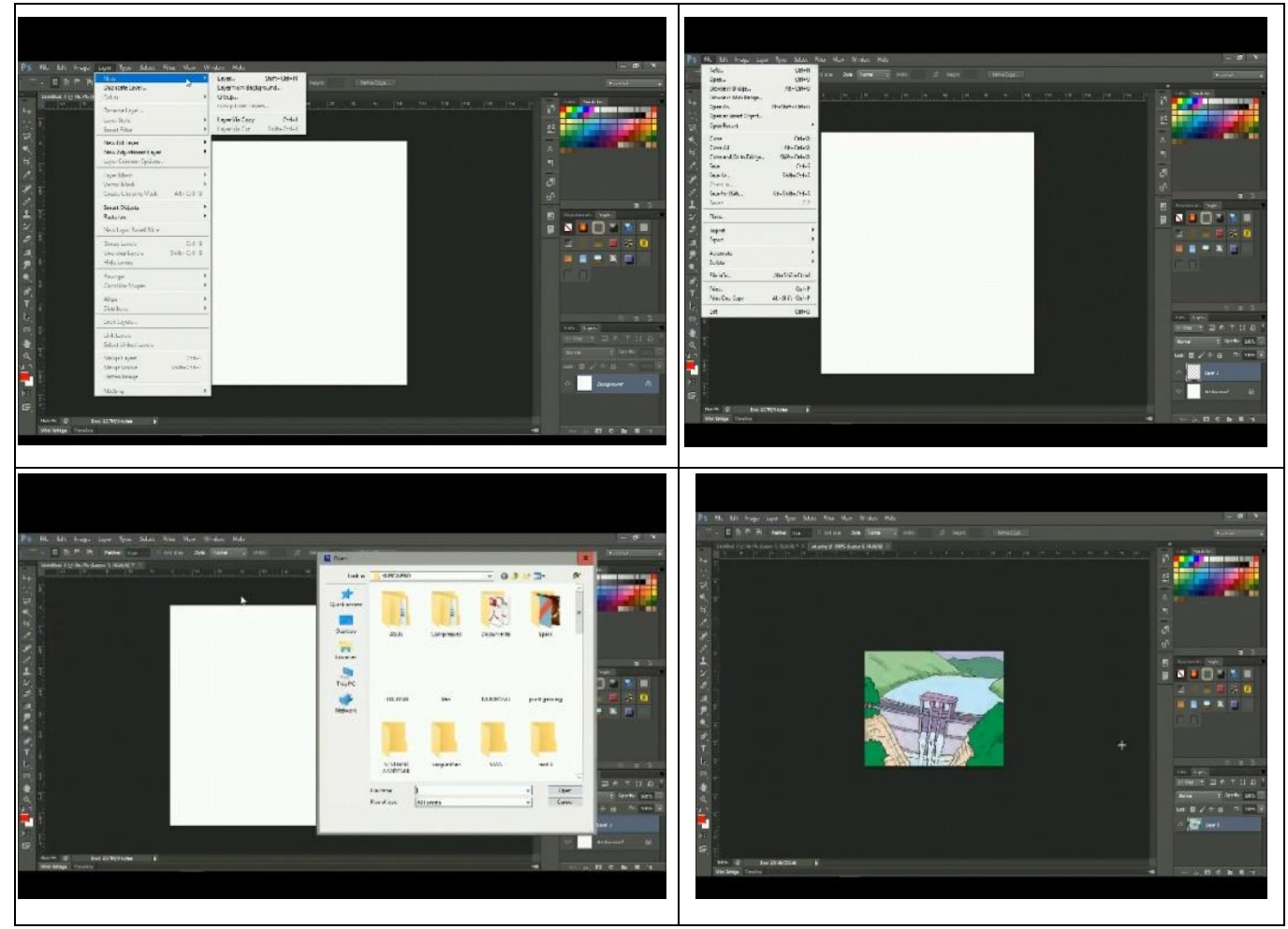

Gambar 1. Desain Gambar Media Puzzle Inovatif

(3) Development (pengembangan) yaitu merakit komponen yang telah dirancang sehingga media pembelajaran puzzle siap digunakan dalam proses pembelajaran serta melakukan uji validasi produk oleh ahli dan uji coba, (4) Implementation (implementasi) yaitu mempersiapkan guru menjadi partner pengembang media pembelajaran dan mempersiapkan siswa untuk mengikuti pembelajaran, dan (5) Evaluation (evaluasi) yaitu melakukan evaluasi terkait data-data yang telah terkumpul.

\section{Validitas Pengembangan Media}

Validasi media pembelajaran puzzle meliputi (1) uji ahli isi mata pelajaran, (2) uji ahli media pembelajaran, (3) uji ahli desain pembelajaran, (4) uji coba perorangan, (5) uji coba kelompok kecil, dan (6) uji coba lapangan.

Uji ahli isi mata pelajaran ini dilakukan oleh guru kelas IV di SD Negeri 2 Bengkala yaitu Bapak Made Mudiarsa. Berdasarkan penilaian dari ahli isi mata pelajaran persentase tingkat pencapaian adalah $97,14 \%$ berada pada kualifikasi sangat baik, sehingga media pembelajaran puzzle tidak perlu direvisi. Uji ahli media pembelajaran ini dilakukan oleh salah satu dosen di Jurusan Teknologi Pendidikan, Fakultas IImu Pendidikan, Universitas Pendidikan Ganesha yaitu Bapak Dewa Gede Agus Putra Prabawa, S.Pd., M.Pd. Berdasarkan penilaian dari ahli media pembelajaran, persentase tingkat pencapaian media pembelajaran puzzle yaitu $70 \%$ berada pada kualifikasi cukup, sehingga media pembelajaran permainan ular tangga direvisi secukupnya. Uji ahli desain pembelajaran ini dilakukan oleh salah satu dosen di Jurusan Teknologi Pendidikan, Fakultas IImu Pendidikan, Universitas Pendidikan Ganesha yaitu Bapak Dr. I Made Tegeh, S.Pd., M.Pd. Berdasarkan penilaian dari ahli desain pembelajaran, persentase tingkat pencapaian media pembelajaran puzzle yaitu $88 \%$ berada pada kualifikasi baik, sehingga media pembelajaran puzzle perlu sedikit direvisi.

Uji coba perorangan dilakukan oleh tiga orang siswa kelas V SD Negeri 2 Bengkala. Berdasarkan hasil analisis data uji coba perorangan, diperoleh rerata persentase $94 \%$ berada pada kualifikasi sangat baik, sehingga media pembelajaran puzzle tidak perlu 
direvisi. Uji coba kelompok kecil dilakukan oleh 6 orang siswa kelas V SD Negeri 2 Bengkala. Berdasarkan hasil analisis data uji coba kelompok kecil, diperoleh rerata persentase $93 \%$ berada pada kualifikasi sangat baik, sehingga media pembelajaran puzzle tidak perlu direvisi. Uji coba lapangan dilakukan oleh seluruh siswa kelas IV SD Negeri 2 Bengkala sebanyak 14 orang siswa. Berdasarkan hasil analisis data uji coba lapangan, diperoleh rerata persentase $97,14 \%$ berada pada kualifikasi sangat baik, sehingga media pembelajaran permainan ular tangga tidak perlu direvisi. Adapun tabel kesimpulan uji validitas sebagai beriku.

Tabel 3. Hasil Uji Validitas Produk

\begin{tabular}{cccc}
\hline Uji Ahli/Siswa & $\begin{array}{c}\text { Hasil } \\
\text { Penilaian }\end{array}$ & Kualifikasi & Keterangan \\
\hline Uji Ahli Isi Mata Pelajaran & $97,14 \%$ & Sangat Baik & Tidak Perlu Direvisi \\
Uji Ahli Media Pembelajaran & $70 \%$ & Cukup & Direvisi Secukupnya \\
Uji Ahli Desain Pembelajaran & $88 \%$ & Baik & Perlu Sedikit Direvisi \\
Uji Perorangan & $94 \%$ & Sangat Baik & Tidak Perlu Direvisi \\
Uji Kelompok Kecil & $93 \%$ & Sangat Baik & Tidak Perlu Direvisi \\
Uji Lapangan & $97,14 \%$ & Sangat Baik & Tidak Perlu Direvisi \\
\hline
\end{tabular}

\section{Efektivitas Pengembangan Media}

Tingkat efektivitas media pembelajaran puzzle dapat diketahui dengan memberikan instrumen tes pilihan ganda kepada seluruh siswa kelas IV SD Negeri 2 Bengkala sebanyak 14 orang siswa. Sebelum media pembelajaran puzzle diterapkan terlebih dahulu diberikan pretest. Selanjutnya setelah media pembelajaran puzzle diterapkan maka seluruh siswa kelas IV diberikan posttest. Nilai rata-rata pretest sebesar 14 dan nilai rata-rata posttest sebesar 19,93. Berdasarkan nilai pretest dan posttest tersebut, maka dilakukan uji-t untuk sampel berkorelasi. Adapun rangkuman hasil uji efektivitas tercantum pada Tabel 5.

Tabel 5. Rangkuman Hasil Uji Efektivitas

\begin{tabular}{cccccccc}
\hline Data & $\mathrm{N}$ & Mean & Varians & $\mathrm{db}\left(\mathrm{n}_{1}+\mathrm{n}_{2}-2\right)$ & $\mathrm{T}_{\text {Hitung }}$ & $\mathrm{T}_{\text {Tabel }}$ & $\begin{array}{c}\text { Keterangan } \\
\mathrm{T}_{\text {Hitung }>\mathrm{T}_{\text {Tabel }}}\end{array}$ \\
\hline $\begin{array}{c}\text { Pretest } \\
\text { Posttest }\end{array}$ & 14 & $\begin{array}{c}14 \\
19,93\end{array}$ & $\begin{array}{c}7,23 \\
6,99\end{array}$ & 26 & 9,240 & 2,056 & Signifikan \\
\hline
\end{tabular}

Hasil perhitungan menunjukkan bahwa $\mathrm{db}=26$ diperoleh nilai $t_{\text {tabel }}$ pada taraf signifikansi $5 \%$ yaitu sebesar 9,240. Berdasarkan perhitungan yang telah dilakukan diperoleh $t_{\text {hitung }}$ yaitu 2,056. Dengan demikian, harga $t_{\text {hitung }}$ yaitu 9,240 lebih besar dari harga $t_{\text {tabel }}$, sehingga $\mathrm{H} 0$ ditolak dan $\mathrm{H} 1$ diterima. Berarti terdapat efektivitas media pembelajaran puzzle dalam meningkatkan kompetensi pengetahuan IPA siswa kelas IV di SD Negeri 2 Bengkala Kecamatan Kubutambahan Kabupaten Buleleng.

\section{Simpulan dan Saran}

Rancang bangun media pembelajaran puzzle menggunakan model ADDIE. Pengembangan dimulai dari tahap (1) Analyze (analisis) yaitu memeriksa masalah yang ada, (2) Design (desain) yaitu merancang bagian dari media puzzle, dan gambar yang sesuai, (3) Development (pengembangan) yaitu merakit komponen yang telah dirancang sehingga media pembelajaran puzzle siap digunakan dalam proses pembelajaran serta melakukan uji validasi produk oleh ahli dan uji coba, (4) Implementation (implementasi) yaitu mempersiapkan guru menjadi partner pengembang media pembelajaran dan mempersiapkan siswa untuk mengikuti pembelajaran, dan (5) Evaluation (evaluasi) yaitu melakukan evaluasi terkait data-data yang telah terkumpul. 
Validitas hasil pengembangan media pembelajaran puzzle pada (1) validitas dari ahli isi mata pelajaran IPA, diketahui bahwa media pembelajaran puzzle yang dikembangkan berada pada kualifikasi sangat baik yaitu 97,14\% dan tidak perlu direvisi. (2) Hasil review media pembelajaran puzzle dari ahli desain pembelajaran diketahui bahwa media pembelajaran puzzle yang dikembangkan berada pada kualifikasi baik yaitu $88 \%$ dan perlu sedikit direvisi. (3) Hasil review media pembelajaran puzzle dari ahli media pembelajaran diketahui bahwa media puzzle yang dikembangkan berada pada kualifikasi cukup yaiu $70 \%$ dan direvisi secukupnya. (4) Validasi dalam uji coba perorangan mendapatkan persentase sebesar $94 \%$ dengan kualifikasi sangat baik dan tidak perlu direvisi. (5) Untuk validasi dalam uji coba kelompok kecil memperoleh persentase 93\% dengan kualifikasi sangat baik dan tidak perlu direvisi. (6) Sedangkan untuk validasi dalam uji coba lapangan mendapat persentase $97,14 \%$ dengan kualifikasi sangat baik tidak perlu direvisi.

Tingkat efektivitas media pembelajaran puzzle dapat diketahui dengan memberikan instrumen tes pilihan ganda kepada seluruh siswa kelas IV SD Negeri 2 Bengkala sebanyak 14 orang siswa. Sebelum media pembelajaran puzzle diterapkan terlebih dahulu diberikan pretest. Selanjutnya setelah media pembelajaran permainan ular tangga diterapkan maka seluruh siswa kelas IV diberikan posttest. Nilai rata-rata pretest sebesar 14 dan nilai rata-rata posttest sebesar 19,93. Berdasarkan nilai pretest dan posttest tersebut, maka dilakukan uji-t untuk sampel berkorelasi.

Hasil perhitungan menunjukkan bahwa $\mathrm{db}=26$ diperoleh nilai ttabel pada taraf signifikansi $5 \%$ yaitu sebesar 9,240 . Berdasarkan perhitungan yang telah dilakukan diperoleh thitung yaitu 2,056. Dengan demikian, harga thitung yaitu 9,240 lebih besar dari harga ttabel, sehingga $\mathrm{H} 0$ ditolak dan $\mathrm{H} 1$ diterima. Berarti terdapat efektivitas media pembelajaran puzzle dalam meningkatkan kompetensi pengetahuan IPA siswa kelas IV di SD Negeri 2 Bengkala Kecamatan Kubutambahan Kabupaten Buleleng.

Adapun saran yang dapat disampaikan yaitu sebagai berikut. Saran yang dapat disampaikan kepada Guru disarankan untuk menerapkan media pembelajaran Puzzle pada mata pelajaran IPA khususnya. Kepala sekolah Disarankan untuk memerikan fasilitas untuk guruguru dalam mengembangkan media pembelajaran yang digunakan untuk kegiatan dalam belajar siswa dikelas. Siswa Disarankan dapat memanfaatkan media pembelajaran Puzzle pada kegiatan belajar khususnya pada mata pelajaran IPA. Peneliti lain Penelitian ini dapat digunakan sebagai bahan kajian penelitian yang relevan dan dapat dikembangkan dengan inovatif dan disarankan agar hasil penelitian ini dapat dijadikan suatu refrensi dalam melakukan penelitian pengembangan yang sejenis.

\section{Daftar Pustaka}

Agung, Gede. 2014. Metodologi Penelitian Pendidikan. Yogyakarta: Aditya Media Publishing.

Agung, Gede. 2015. Statistika Inferensial. Singaraja: Undiksha.

Alamuddin. 2013. "Penilaian Dalam Kurikulum 2013". Jurnal Prosiding Seminar Nasional. Vol. 01. No. 1(hlm. 24-214).

Aly Abdullah \& Rahma Eny. 2009. Ilmu Alamiah Dasar. Jakarta: Bumi Aksara.

Arsanti, Meilan. 2018. "Pengembangan Bahan Ajar Mata kuliah Penulisan Kreatif Bermuatan Nilai-Nilai Pendidikan Karakter Religius Bagi Mahasiswa Prodi PBSI, FKIP, UNISSULA". Jurnal Kredo, Volume 1, Nomor 2 (hlm. 71-90).

Arsyad, Azhar. 2009. Media Pembelajaran. Jakarta: Rajawali Pers.

Asyhar, Rayandra. 2012. Kreatif Mengembangkan Media Pembelajaran. Jakarta: Referensi Jakarta.

Arifuddin, Ahmad, dkk. 2017. " Pengaruh Penerapan Alat Peraga Puzzle dengan Menggunakan Metode Demonstrasi Terhadap Motivasi Belajar Siswa Pada 
Pembelajaran Matematika di SD/MI". Jurnal IImiah Sekolah Dasar, Vol. 2, No. 1 (hlm. 11-17).

Denpykora, Decky, dkk. 2018. "Pengaruh Model Pembelajaran Kooperatif Tipe Team Game Tounament (TGT) Berbantuan Media Puzzle Materi Jenis-Jenis Ekosistem Terhadap Prestasi Belajar Siswa Kelas V". Internasional Journal of Elementary Education. Volume 2. Number 4 (hlm. 291-297).

Elan, dkk. 20017. "Penggunaan Media Puzzle Untuk Meningkatkan Kemampuan Mengenal Bentuk Geometri”. Jurnal PAUD Agapedia. Vol. 1. No. 1 (hlm. 67).

Falak, Samsul. 2016. "Tingkat Kompetensi Pengetahuan Perpustakaan Bagi Guru Madrasah Melalui Diklat Substantif Pembekalan Penugasan Tambahan Calon Kepala Perpustakaan”. Jurnal KHIZANAH AL-HIKMAH. Vol. 4. No. 1 (hlm. 65-75).

Gayatri, Aulia Nofa, dkk. 2018. "Keefektifan Model Make A Match Berbantuan Media Kartakalung Terhadap Hasil Belajar Matematika Siswa”. Jurnal Ilmu Sekolah Dasar. Volume 2. Number 4 (hlm. 475-481).

Indrayani, Putu Susma, dkk. 2014. "Pengaruh Model Pembelajaran Kooperatif Tipe Ttw Berbasis Kearifan Lokal Tri Kaya Parisudha Terhadap Hasil Belajar IPA pada Siswa Kelas V SD". Singaraja, Volume 2 Nomor 1.

Kasri. 2018. "Peningkatan Prestasi Belajar Matemattika melalui media Puzzle Siswa kels 1 SD”. Jurnal Pendidikan: Riset \& Konseptual. Vol. 2 No. 3 (hlm. 320-325).

Koyan, I Wayan. 2011. Assesmen Dalam Pendidikan. Singaraja: universitas Pendidikan Ganesha.

Koyan, I Wayan. 2012. Statistik Pendidikan. Singaraja: Universitas Pendidikan Ganesha.

Maulida, Achlisha \& Zulfitria. 2017. "Pengembangan Kecerdasan Interpersonal Anak Autis Melalui Pemanfaatan Media Puzzle pada Siswa kelas 2 Sekolah Dasar". Jurnal IImiah PGSD. Volume 1 No. 2 (hlm. 120-130).

Musfiqon, HM. 2012. Pengembangan Media dan Sumber Pembelajaran. Jakarta: PT. Prestasi Pustakarya.

Purwani, Ni putu rita, dkk. 2018. "Pengaruh Model Pembelajaran Picture and picture Berbasis Portofolio Terhadap Hasil Belajar IPA Siswa". Internasional Journal of Elementary Education. Volume 2. Number 3 (hlm. 166-172).

Purwanto, 2009. Evaluasi Hasil Belajar. Yogyakarta: Pustaka Pelajar.

Putri, Ni M.C.D, dkk. 2018. "Pengaruh Model Discovery Learning Berbantuan Lingkungan Terhadap Kompetensi Pengetahuan IPA Kelas V". Internasional Journal of Elementary Education. Volume 2. Number 3 (hlm. 212-218).

Rakhma, Ifa Seftia dkk. 2016. "Pengembangan Magic Crossword Puzzle Sebgai Media Pembelajaran IPA untuk Siswa kelas V Sekolah Dasar". Jurnal Refleksi Edukatika. Volume 7. Nomor 1(hlm. 70-77).

Retnoningsih, dkk. 2013. "Pengembangan Kognitif Melalui Penerapan Metode Pemberian Tugas Berbantuan Media Puzzle Angka Pada Anak Kelompok A semester II TK ATH-THORRIQ Singaraja Tahun Pelajaran 2012/2013". Jurnal universitas Pendidikan Ganesha. Vol. 1. No. 1 (hlm. 1-10).

Rumakhit, Nur. 2017. "Pengembangan Media Puzzle untuk Pembelajaran Materi Mengidentifikasi Beberapa Jenis simbolis dan Rantai Makanan klas IV Sekolah Dasar Tahun 2016/2017". Jurnal Universitas Nusantara PGRI Kediri. Vol. 01. No. 02 (hlm. 1-9). 
Sadiman, Arief S, dkk. 2009. Media Pendidikan: Pengertian, Pengembangan dan Pemanfaatannya. Jakarta: Rajawali Pers.

Samatowa, Usman. 2010. Pembelajaran IPA di Sekolah Dasar. Jakarta: PT Indeks.

Saubbaissagu, Valeria. 2016. "Penggunaan Media Puzzle untuk Meningkatkan Motivasi Belajar IPA Siswa Kelas II B SD Negeri Gedongkiwo". Jurnal Pendidikan Guru Sekolah Dasar. Vol. 5. No. 38

Suarjana, I Made \& Japa. 2015. Pendidikan Matematika III. Jurusan Pendidikan Guru Sekolah Dasar : Singaraja.

Suarno, Dendi Tri dan Sukirno. 2015. "Pengembangan Media Pembelajaran IPS dengan Tema Pemanfaatan dan Pelestarian Sungai untuk Siswa Kelas VII SMP”. Harmoni Sosial. Jurnal Pendidikan IPS, Volume 2, Nomor 2 (hlm. 155-125).

Sudarma, I Komang, dkk. 2015. Desain Pesan Kajian Analitis Desain Visual. Graha IImu: Yogyakarta.

Suprijono, Agus. 2009. Cooperative Learning Teori dan Aplikasi PAIKEM. Yogyakarta: Pustaka Pelajar.

Susanto, Ahmad. 2013. Teori Belajar dan Pembelajaran di Sekolah Dasar. Jakarta. Prenadamedia Group.

Susanto, Ari Prabawati \& Fitria Evy. 2018. "Upaya Meningkatkan Konsep Bilangan Melalui Puzzle Angka Pada Anak Usia 4-6 Tahun". Jurnal Program Studi Pendidikan Anak Usia Dini. Vol. 7. No. 2 (hlm. 2-11).

Suwatra, I Wayan, dkk. 2015. Belajar dan Pembelajaran Sekolah Dasar. Singaraja: Universitas Pendidikan Ganesha.

Tegeh, I Made \& Kirna. 2010. Meetode Penelitian Pengembangan Pendidikan. Singaraja: Universitas Pendidikan Ganesha.

Tegeh, I Made, dkk. 2014. Model Penelitian Pengembangan. Singaraja: Graha Ilmu.

Tegeh, I Made, dkk. 2012. Seminar Pendidikan. Singaraja: Universitas Pendidikan Ganesha.

Undang-Undang R.I. Nomor 20 Tahun 2003 tentang SISDIKNAS \& Peraturan Pemerintah R.I. Nomor 47 Tahun 2003. 2008. Bandung: Citra Umbara. 